\title{
Forced to flee: A multi-disciplinary conference on internal displacement, migration and refugee crises
}

London, 7-8 November 2016, SOAS University of London, Arts and Humanities Research Council, University of Exeter, British Red Cross and ICRC

\section{Conference report *}

* This report is a summary of a conference. The views expressed here are those of the participants concerned, and not necessarily those of the organizations that they represent: the ICRC, the British Red Cross, SOAS University of London, the Arts and Humanities Research Council and the University of Exeter. It was drafted based on notes taken by Matt Shin, and edited by Jovana Kuzmanovic and Ellen Policinski of the Review editorial team. Special thanks to Andrew Thompson of the Review Editorial Board, and Sarah Cotton and Markus Geisser of ICRC London. 


\section{Executive summary}

"Forced to Flee" was a multidisciplinary two-day conference on internal displacement, migration and refugee crises, jointly organized by SOAS University of London, the Arts and Humanities Research Council, the University of Exeter, the British Red Cross and the International Committee of the Red Cross (ICRC). It brought together some sixty researchers, independent and UK government policy-makers, and senior humanitarian practitioners.

The central principle and premise of the event was that looking to past mass displacement crises can provide insights for the present, as forced displacements have been a frequent phenomenon in human history. Today, the numbers of people being forced to leave their homes have reached levels that have not been seen since the end of the Second World War. Forced displacement affects men and women, the old and the young, people on their own or in large groups - all can be forced to flee their homes and seek refuge elsewhere.

History can teach us about the roots causes that produce refugee flows, the responses of destination countries and the changing status of refugees, internally displaced persons (IDPs) and migrants. To that end, the ambition behind the "Forced to Flee" conference was to use history to inform current debates on forced displacement and bring in a different perspective to public discourse in which refugees, IDPs and other migrants have been subject to wider political pressures that have served to undermine human rights and humanitarian norms.

Over the course of two days, experts addressed the stubborn realities of how best to protect those forced to flee their homes, seek sanctuary and rebuild their lives. They examined and reflected on several issues: the experiences of the forcibly displaced, the root causes of mass displacement from the First World War until today, the evolution of humanitarian and development policy and practice when responding to crises of mass displacement, and the evolution of legal mechanisms that have provided a regulatory framework for refugees over the past hundred years.

Many conclusions were drawn by the speakers - among others, that the vulnerabilities of refugees, IDPs and migrants have repeatedly served as a catalyst for new thinking about emergency relief and development aid. The conference included an accompanying high-level public panel which focused on taking stock of how the international community, faced by millions of people displaced from their homes every year, can do better.

\section{Introduction}

On 7-8 November 2016, SOAS University of London, the Arts and Humanities Research Council, the University of Exeter, the British Red Cross and the International Committee of the Red Cross (ICRC) brought together some sixty researchers, independent and UK government policy-makers, and senior 
humanitarian practitioners for a multidisciplinary conference examining mass migration crises via the lens of history.

In 2015, there were reportedly some 20 million refugees and 40 million internally displaced persons (IDPs) worldwide. ${ }^{1}$ In addition, there are many socalled "economic" migrants, who are also vulnerable to violence-including kidnapping, human trafficking, extortion and sexual violence - along the route to their destination, and many are detained or interned. History can help us to understand the realities that the international community struggles with today, including the roots of the crises that lead to displacement, responses in destination countries, and the statuses of refugees, IDPs and other migrants.

The "Forced to Flee" conference looked at the evolution of State, humanitarian and development policy in responding to mass displacement over the past hundred years, as well as the legal mechanisms protecting people who are forced from their homes. It gathered researchers and policy-makers to discuss these issues more than a hundred years since the first regulatory frameworks were developed and international agencies were established to respond to the needs of refugees. Participants included Marc Bosch Bonacasa, Médecins Sans Frontières; David Cantor, School of Advanced Study, University of London; Sarah Collinson, Overseas Development Institute; Michael Collyer, University of Sussex; Robert Fletcher, University of Warwick; Maria Framke, University of Rostock; Peter Gatrell, Manchester University; Laura Hammond, SOAS University of London; Laure Humbert, University of Manchester; Clea Kahn, British Red Cross; Jo Laycock, Sheffield Hallam University; Paolo Novak, SOAS University of London; Ilan Pappé, University of Exeter; Jonathan Prentice, International Crisis Group; Ruba Salih, SOAS University of London; Heike Schmidt, University of Reading; Ronald Skeldon, Maastricht University; Claudena Skran, Lawrence University; Ashley South, Chiang Mai University; Fiona Terry, Independent Researcher; Andrew Thompson, University of Exeter and Interim Chief Executive of the UK Arts and Humanities Research Council; and Myles Wickstead, King's College London and University of Exeter.

As part of the conference, there was also a public event featuring a highlevel debate entitled "With Millions on the Move, the World Must Do Better. But How?". ${ }^{2}$ The debate was moderated by Lauren Taylor from Al Jazeera and featured Valerie Amos, Director of SOAS University of London and formerly UN Undersecretary-General for Humanitarian Affairs and Emergency Relief Coordinator; Kelly Clements, United Nations (UN) Deputy High Commissioner for Refugees; Abdurahman Sharif, Director of the Somalia NGO Consortium, Nairobi; and Dominik Stillhart, ICRC Director of Operations.

Participants considered developments in the way the international community responds to waves of mass displacement by looking back in time over

1 Figures taken from Office of the UN High Commissioner for Refugees (UNHCR), Global Trends: Forced Displacement in 2015, 20 January 2016, available at: www.unhcr.org/576408cd7.pdf (all internet references were accessed in June 2017).

2 The event's website is available at: www.soas.ac.uk/cas/events/07nov2016-forced-to-flee-with-millionson-the-move-the-world-must-do-better-but-how.html. 
the past century, starting with the period 1914-1939, where population flows during and after the First World War led to the birth of today's regulatory and protection frameworks for addressing displacement. The definition of "refugee" was still quite loose at this time, and assistance was provided to displaced persons based on sympathy for a particular group, thus tying receipt of assistance to group identities such as nationality or religion. Conference participants then looked back to 1940-1959, the period covering the Second World War and the beginning of the Cold War. During that era the international legal regime for refugees was established, notably through the negotiation of the 1951 Convention relating to the Status of Refugees (Refugee Convention). This time period also saw the rise of organizations dedicated to providing humanitarian relief. The period between 1960 and 1989 saw decolonization, postcolonial civil wars, neocolonialism, economic "miracles" in the West and the effects of proxy wars associated with the Cold War, which acted as drivers of displacement. The high visibility of mass migration driven by these multiple causes led to the expansion of humanitarianism.

Next, the participants looked at the period beginning with the fall of the Berlin Wall in 1989 and watershed events of the 1990s and 2000s such as the Rwandan Genocide and the Balkan Wars, the September 11 attacks in the United States and the ensuing era of instability, chaos and insecurity that the "September 11 wars" have created. This was a period that saw the pendulum swing from a breaking down of borders at the end of the Cold War to their reinforcement as attitudes changed in the wake of the September 11 attacks. For the period covering 2003 through to the present, the conference looked at the dynamics spawned by Western interventions in Afghanistan and Iraq, the tumultuous changes that have rocked the Middle East since 2011, and the brutal realities that migrants endure in Central America and Africa. The participants analyzed the challenges we are faced with today and discussed ways of better understanding and engaging with forcibly displaced populations, evaluating the continued relevance of the Refugee Convention and looking toward the future.

By tracing the evolution of the international response to waves of mass displacement over the past century, we can draw lessons for the present. The report below is a summary of the main points that were debated during the conference.

\section{Assistance based on group identity and a loose definition of "refugee"}

In the period during and after the First World War, population flows caused by the world war led to the birth of today's regulatory and protection frameworks for addressing displacement. At the time of the First World War, the term "refugee" had yet to evolve into a concrete legal concept. Humanitarian assistance was provided to displaced persons based on the identity of the group they belonged 
to, rather than out of a feeling of sympathy, and thus was not necessarily impartial or neutral in character.

For example, when campaigns waged by British and Ottoman forces triggered desperate movements of displaced nomadic groups, with governments unable to police movements across porous borders, displaced Bedouins faced different treatment depending on the sympathy of the assisting power. Some of the powers in the Middle East favoured the relocation of the "refugee tribes", while others saw them as political instruments. The various official responses to displaced nomads show how the politics of definition and categorization affected refugees at the time. Nomadic peoples were particularly exposed to this, with cultural assumptions about their rootlessness blurring the line between the categories of "refugee", "raider" and "rebel".

The origins of today's refugee protection regime can arguably be traced to the former Russian Empire, where the forced displacement of civilians during the First World War saw more than 14-15 million people being uprooted. Yet, this mass movement is absent from the orthodox "refugee canon", as the betterknown flight of anti-Bolsheviks after 1917 has diverted attention from it, and from its momentous consequences. Precisely because this crisis of forced mass displacement is less well known, historical analysis of it can shed light on the issues involved - that very lack of familiarity can disturb our views about the origins, causes and outcomes of refugee crises.

These early refugee crises gave birth to the response patterns observed a hundred years later. In some instances, private, voluntary organizations (PVOs) formed to assist particular displaced groups based on national identity. PVOs were the precursors to today's NGOs, though with some differences - important among them being the fact that many were not professional organizations. Between 1921 and 1922, PVOs were able to exert influence by helping to set the agenda through their own initiatives, and by being political actors in national governments. They thus played a vital role in establishing the refugee activities of the League of Nations.

Another example is that of Russian refugees stranded in Constantinople in 1921 - very much seen as the "first" "international refugee crisis" - where some of the millions that fled the Russian civil war received international press coverage and captured the attention of international aid organizations, governments and the newly formed League of Nations. Similar attention was garnered in 1922 when refugees fled from Turkey to Greece. Together, these two crises helped shape the first international refugee regime, centred around a High Commission for Refugees appointed by the League of Nations, but with funding from PVOs playing a vital role.

Once the League of Nations High Commission for Refugees was created in 1921, the term "refugee" was increasingly used solely to designate people outside their own country. However, they were also largely defined by membership of a group, such as a national or religious group. The term "refugee" was still relatively loosely applied, and there was little concern for the motivations of individuals within these groups in deciding to leave. 


\section{The establishment of the international legal regime for refugees and the rise of organizations providing relief}

The displacement caused by the Second World War and the setting-in of the Cold War saw the establishment of the Refugee Convention, and with it a legal definition of the term "refugee", ${ }^{3}$ as well as the creation of an international apparatus for responding to displacement crises through the UN. The ways in which mass population movements were dealt with during this period shaped the legal, practical and research lenses through which the international community understands and responds to displacement.

International organizations in Allied Occupied Germany, including the UN Relief and Rehabilitation Administration (UNRRA) and later the International Refugee Organisation, greatly influenced the drafting of the Refugee Convention. Although these organizations worked for the benefit of refugees, it is worth examining the degree of continuity and rupture in relief policy and humanitarian assistance in the aftermath of the Second World War. For instance, UNRRA provided psychological rehabilitation, considering not only the physical needs of refugees but also their mental state. This could be seen as marking a new form of humanitarianism, although it was not entirely new - the League of Nations had already included an agenda to help refugees recover from the trauma of displacement and become full-fledged members of society. There were different visions of relief in the various Occupied Zones.

Also during this time period, large-scale violence resulted from the partition of the Indian subcontinent following independence, causing the displacement of some 12 million people. Initially, governments were unable to cope with the needs of the refugees, and the setting-up of government-sponsored relief was slow. Various regional, national and international NGOs worked to provide aid for refugees and other victims of partition, including many Indian branches of non-State organizations, such as the Indian Red Cross, Young Men's Christian Association and St John's Ambulance, which often needed to set up separate Pakistani branches as well as Indian ones. Many other organizations providing relief did not understand themselves as humanitarian, but rather were political, religious or cultural organizations. As seen in the mass displacement crises in the post-First World War period, aid was still often selective, with relief provided not necessarily on an impartial basis but rather based on membership of a particular group, such as a religious group. Even for larger non-State organizations, neutrality and impartiality were not necessarily a given.

3 See Convention relating to the Status of Refugees, 189 UNTS 150, 28 July 1951 (entered into force 22 April 1954), Art. 1(A)(2), which defines "refugee" as a person who was either already considered a refugee under previous conventions or who "owing to well-founded fear of being persecuted for reasons of race, religion, nationality, membership of a particular social group or political opinion, is outside the country of his nationality and is unable or, owing to such fear, is unwilling to avail himself of the protection of that country". The definition was subsequently revised by the Protocol relating to the Status of Refugees, 606 UNTS 267, 31 January 1967 (entered into force 4 October 1967). Both the Convention and the Protocol are available at: www.unhcr.org/1951-refugee-convention.html. 


\section{Multiple drivers of displacement and the expansion of humanitarianism}

Mass displacement crises from the 1960s to the end of the 1990s were shaped by the intersection of three political forces - new and accelerating forms of globalization, the Cold War, and decolonization. The dynamics of global decolonization set in motion a whole matrix of mobility, some of it voluntary, some coerced, and much not clearly one or the other. Decolonization exposed the limitations of the Refugee Convention, since its way of separating refugees, IDPs and economic migrants bore little resemblance to what was happening on the ground. The multiple drivers of displacement during the various wars of liberation and nationalist resistance during this period included chronic poverty, land expropriation, violence, racial hostilities, secessionist movements and postcolonial civil wars. The forms of displacement were also many and varied-from relocation into what were euphemistically called "protected" or "consolidated" villages in Zimbabwe to the expulsion of non-white populations with links to the former colonial power, such as the Ugandan Asians. Then there were the largescale movements of formerly colonized peoples to Europe after independence (often these were technically not immigrants, but internal migrants), and the migration of former soldiers, for example from Mozambique and Angola to Portugal.

Moreover, decolonization complicated the question of who was a refugee and who was a migrant. It was difficult to distinguish those who had no choice but to leave from those who were violently displaced, those moving in search of opportunity or asylum-seekers fleeing persecution. Patterns of flight followed the "grooves of memory" as people fled to the places they knew or had heard about.

During this time, aid organizations were largely relegated to refugee camps on the borders of conflict areas, and these camps were often highly militarized. Refugees were welcomed by host States as political pawns, showing the savagery of their opponents. The politicization of refugees was hard to escape, and aid agencies often had to choose who to support. The end of the Cold War also brought an end to this - refugees were no longer political emblems, and the UN Security Council also was no longer constricted by the constant threat of a veto. There was optimism that things would get better, with organizations now able to come into the heart of conflict zones and subject to fewer constraints. There was expansion among agencies set up to respond to mass displacement crises, as well as in the UN's role. However, these organizations were often plunged into direct political involvement in conflict situations. Cold War considerations, in particular, politicized the emerging international human rights regime. At the sharp end of action, humanitarian organizations could find themselves working in militarized refugee camps or being pitched into counter-insurgency campaigns. 


\section{The restoration of borders}

The post-Cold War period saw international crisis and geopolitical change associated with watershed moments such as the fall of the Berlin Wall, the dissolution of the Soviet Union and the end of the Cold War proxy conflicts. The year 1989 was a turning point in the migration debate, when "forced migrants" became "economic migrants".

The optimism of the new world order discourse that characterized the early 1990s came already to a grinding halt in Somalia in 1993. With the failure of US military intervention, the purpose of which was humanitarian, the idea of the United States as the world policeman died. Then came the defining moment during the genocide in Rwanda, when aid became a tool for foreign policy disengagement, given the lack of appetite for intervention. Since then, the international community has slowly crept back to humanitarianism and foreign policy being linked. Kosovo was the first example, with NATO troops setting up refugee camps. This raised concerns for humanitarians, as it went against the idea of aid as neutral and impartial. Humanitarian organizations began to seriously examine the ethical issues raised by the role of aid vis-à-vis politics.

Contemporary dynamics spawned by the Western interventions in Afghanistan and Iraq, the tumultuous changes that have rocked the Middle East since 2011 and the brutal realities that migrants endure in Central America and Africa have led many States to adopt policy approaches that seek to limit migration. During this period it has become increasingly clear that borders are far more complex than lines on a map. Migration control has extended beyond State territory, and continues, in many respects, once individuals arrive in their host countries. When nation-States came into being, they were made and unmade at the border; now, with the nation-State model in crisis, States have fortified their borders.

More recently, migration control organizations have started to rescue migrants in distress at sea, particularly in the Mediterranean, as public anger at the loss of life has grown. This "humanitarian border" is complex, but continues to operate as a formal barrier or filter. "Humanitarian border management" refers to border management policies that are specifically designed to meet humanitarian objectives. There are contradictions built into this concept. Border management has a dual imperative: it is concerned on the one hand with the security of States, and on the other with the needs of people requiring protection. This conflates views of migrants both as people at risk and as people posing a risk, compounded by the mobilization of law enforcement and the military in border management. More reflective analysis of humanitarian border management is needed, in particular on what challenges it poses to migration and how it could be politicized.

Given the role of the border as a filter, the location of the border is no longer as relevant as the function of the border - "bordering" now takes place in a range of locations. This process is widely described in terms of a "networked 
border", in which control has moved in, out, up and down. The networked border covers a vast area, including the use of development aid to prevent people from moving and the use of humanitarianism as a direct tool of border control or a way of preventing migration.

At the same time, there has been a return to physical borders - there are now more border walls around the globe than at any time since the fall of the Berlin Wall. Such border walls are essentially a public relations exercise, designed to reassure people and show that governments are "doing something" despite evidence that they do not stop migration.

States currently seem to prefer a politics of containment for mass displacement. The trend in EU policy towards investing in the regions that refugees come from, through development, border management, the building of barriers or the externalization of borders, is meant to cause a net reduction in people on the move. There is little evidence for this, however - even development is not having a measurable impact on migration. The evidence shows that where people have more economic wherewithal, they use it to move. Furthermore, the goal should not be to force individuals to make particular decisions, but to enable them to make safe choices.

\section{Relevance of the Refugee Convention today: Is the law sufficient?}

The Refugee Convention is seen by some as a high point for international refugee law, while others suggest that it is not fit for purpose. In fact, its definition of a "refugee" is still the rule under international law, a very clear statement that is still entirely relevant. However, the Convention is only designed to cover refugees as defined in its Article 1, part of a much larger category of people on the move.

The Refugee Convention's definition of "refugee" is centred around the lack of the protection of a State and the fear of persecution. The lack of protection of a State applies to perhaps a billion people, not only migrants but also victims of bonded labour and others for whom migration could be the only way out. Some resist any clear distinction between refugees and migrants, in particular given the tone of public debate, which has introduced the idea that migrants are unprotected, while refugees are morally unassailable. Nevertheless, labels like "refugee" remain significant in that they entail a set of legal protections, but at the same time the validity of the Refugee Convention is under scrutiny. This is perhaps due to a fundamental problem in attitudes toward migration: the international system does not see things from the perspective of vulnerable migrants, but instead attempts to attach labels to people on the move that are sometimes meaningless to the people themselves. It is important to control the terms used in this debate and to choose them carefully, as labels can frame the debate for good or for ill.

It can be easy to point to failures of the law, but there are also positives that the legal system has brought into play over the last century, contributing to the protection of hundreds of millions of people. If the criterion of success is that the 
law is never broken, then all laws would have to be thrown out. In order to consider whether refugee law has been successful, one must look to factors extraneous to the law itself. To the extent that States do not apply refugee law, it is not necessarily the law that is the problem, but rather other factors, such as political ones.

There may be another way to evaluate the effectiveness of the law: by asking whether it is sufficient. There are clear problems with the current legal regime - for example, the notion of burden-sharing is non-existent, and the means of reaching a place where it is possible to claim asylum are criminalized. Furthermore, States seemingly have impunity for non-compliance with refugee law, such as "pushbacks" to refugees' States of origin that happen in Europe. Since being present outside the territory of the State of origin is a requirement for refugee status, there is also the question of physical access to the protections written into the main instruments of refugee law. The bottom line is that the body of law on asylum is well developed and codifies the protections that asylum-seekers should benefit from, but it is becoming harder and harder to access those protections.

\section{Looking ahead}

In German, the word Heimat transcends the ideas of "home" and "homeland", evoking a deep sense of social and cultural belonging, and amounting to safety and security. Refugees, IDPs and other vulnerable migrants have lost their Heimat. Some 65 million people are forcibly displaced and vulnerable today, with 40 million of these being internally displaced - and of course, there are individual tragedies behind every number. There needs to be accountability for States to ensure that they live up to their obligations. The international community needs to invest in (1) diplomatic efforts to end conflict and alleviate the impact of conflict while it is raging, (2) financial efforts to assist communities affected by conflict and to protect vulnerable migrants, and (3) political efforts to give forcibly displaced people a chance to build new lives, to build a new Heimat.

History can inform the present on the current challenges and dynamics surrounding mass displacement, and help us to take stock of the current crisis. With record numbers of forcibly displaced people, especially within countries that are ravaged by armed conflict - and confronted by an international system that has frequently failed to find a solution to protracted conflicts - humanitarian practitioners and policy-makers must decide how to respond. Coverage of migration in the media over the past ten years shows an increasing tendency to "blame" refugees. ${ }^{4}$ However, seen through the lens of history, this crisis is not more alarming than the others encountered by the international community in

4 For example, an IPSOS poll has found that $40 \%$ of people think that immigration is the main problem now facing the UK. See "Immigration One of the Biggest Issues for Wavering EU Referendum Voters", Ipsos MORI, 10 May 2016, available at: www.ipsos.com/ipsos-mori/en-uk/immigration-one-biggest-issueswavering-eu-referendum-voters?language_content_entity=en-uk. 
the past. In pure statistical terms, a world of 7.5 billion people should be able to care for a population of 65 million forcibly displaced.

Today, $86 \%$ of refugees are in developing countries; the top six host countries in Africa have three times the number of refugees as the top six in Europe. One example is the Dadaab refugee camp in Kenya, home to some 350,000 people, which the Kenyan government has announced that it will close. The options for residents of the camp are voluntary repatriation back to Somalia, local integration, or resettlement in another country like the United States or in Europe. Of the people in the camp, most want to return to urban centres in the south of Somalia, but there are already thousands of IDPs there. From an NGO perspective in Somalia, return is not a "durable solution" - reintegration is. This is about a multi-stakeholder approach: it requires collective responsibility, involving development actors, humanitarian actors and human rights actors, and with a legal framework to protect people who return. This has to be an integrated approach that looks not just at people going back from Dadaab, but at people displaced within Somalia, and host communities. There need to be strong channels of communication to keep people informed.

Unilateral action is not enough in responding to mass displacement. There is a need for a truly comprehensive, collective approach. Developing countries bear the greatest economic and social burden in hosting refugees, and they need support. Global efforts to protect the forcibly displaced culminated in the New York Declaration, adopted in September 2016 by 193 countries at the UN General Assembly. ${ }^{5}$ Faced with a global crisis of forced displacement, the New York Declaration commits nations to solidarity in combating abuses. Its language is allencompassing, from the causes of flight to solutions, with repeated reference to long-term development. The development of a Global Compact, setting out key elements of effective response to large waves of displacement, is now under way. The Global Compact is to be presented to the General Assembly and adopted in September 2018. ${ }^{6}$

The plight of IDPs, who have not crossed an international border and therefore are not subject to the same legal protections as refugees, should get more attention, and so should the root causes of displacement, in particular the relevance of international humanitarian law in addressing those root causes. It is not only warfare that causes refugees to flee, but repeated violations of international humanitarian law: the targeting of civilians, for example. A greater respect for the laws of war would address some of the root causes of displacement.

States can do more. They support armed forces (both State and non-State), and that gives them opportunities to influence these parties' behaviour. The bottom line should be no support without compliance with international norms.

5 New York Declaration for Refugees and Migrants, UN Doc. A/RES/71/1, 3 October 2016, available at: refugeesmigrants.un.org/declaration.

6 For more information on the two Global Compacts envisioned by the New York Declaration, namely the Global Compact for Safe, Orderly and Regular Migration, and the Global Compact on Refugees, see: refugeesmigrants.un.org/migration-compact and refugeesmigrants.un.org/refugees-compact. 
In the last few years in Europe, the public has begun to understand the scale of migration, especially with the arrival of Syrian refugees. At the same time, the level of inaction in everyday reality is staggering. There must be greater accountability for States to make the international protections that we have meaningful. The targeting of schools and hospitals, forcing children to become combatants - these are things that everyone can agree are unacceptable, and States can shame other States into being more responsible. Additionally, the international community can be tougher on countries that are themselves in conflict; for example, when governments say that no aid can go to areas where there are opposition groups.

The discussion that took place over the course of the "Forced to Flee" conference provided a sobering reminder of how the past tends to repeat itself. Former UN High Commissioner for Refugees Sadako Ogata once famously remarked that "there are no humanitarian solutions to humanitarian problems". There are only political solutions. Over centuries people forced to flee have been used as pawns for political objectives, relocated against their will, parted from their family members, induced to return under false pretences and pushed back across borders. History is full of reminders that there was never a golden age of respect for the rights of refugees, or of IDPs.

Perhaps, despite the tendency to focus on the plight of people once they are on the move, it is the root causes of displacement that should be seen as key. However, consideration of root causes and the dynamics of refugee displacement is fundamentally political, and addressing them is a step into the realm of international intervention, regime change and stabilization, which are themselves major causes of conflict. The current refugee crisis as seen from Europe is not only about root causes, but also about what happens to people along the way. People can start off as economic migrants and become vulnerable during the journey. In fact, it is not the movement of persons that is the problem, it is the movement of persons without the protection of fundamental rights and norms.

7 Vivian Tan, "Ogata Calls for Stronger Political Will to Solve Refugee Crises", UNHCR, 27 May 2005, available at: www.unhcr.org/news/latest/2005/5/4297406a2/ogata-calls-stronger-political-solve-refugeecrises.html 